\title{
A Short Version of the Big Five Inventory (BFI-20): Evidence on Construct Validity do
}

Valdiney Veloso Gouveia ${ }^{a}$, Rafaella de Carvalho Rodrigues Araújo ${ }^{\text {a }}$ (1), Isabel Cristina Vasconcelos de Oliveira ${ }^{a}{ }^{\circ}$, Marina Pereira

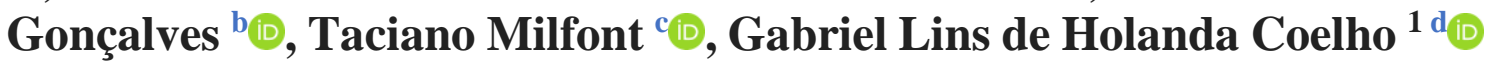
, Walberto Santos ${ }^{\mathrm{e}} \mathbb{D}$, Emerson Diógenes de Medeiros ${ }^{\mathfrak{f}}{ }^{\mathbb{D}}$, Ana Karla Silva Soares ${ }^{\mathrm{g}}{ }^{\mathbb{B}}$, Renan Pereira Monteiro ${ }^{\mathrm{h}}{ }^{\mathrm{D}}$, Josemberg Moura de Andrade ${ }^{\mathrm{i}}{ }^{\circ}$, Thiago Medeiros Cavalcanti ${ }^{\mathrm{j}}{ }^{\oplus}$, Bruna da Silva Nascimento ${ }^{\mathrm{k}}$,, \& Rildésia Gouveia ${ }^{1}\left({ }^{2}{ }^{2}\right.$

Universidade Federal da Paraíba, João Pessoa, Brasil. a; Universidade Federal do Vale do São Francisco, Petrolina, Brasil b; The University of Waikato, Hamilton, New Zealand ${ }^{\mathrm{c}}$; Coláiste na hOllscoile, Corcaigh, Éire '; Universidad Federal de Ceará, Fortaleza, Brasil ${ }^{\text {e }}$; Universidade Federal do Piauí, Teresina, Brasil f; Universidad Federal de Mato Grosso del Sur, Campo Grande, Brasil ". Universidade Federal de Mato Grosso, Cuiabá, Brasil $^{\text {h }}$; Universidade de Brasília, Brasilia, Brasil ${ }^{\text {; }}$ Colégio Santa Maria, São Paulo, Brasil ${ }^{\mathrm{j}}$; University of Bath, Bath, England ${ }^{\mathrm{k}}$; University Centre of João Pessoa, João Pessoa, Brasil ${ }^{1}$.

\begin{abstract}
Several measures were developed in the past decades to measure personality, focusing on the Big Five Factor Model (BFFM; Openness, Conscientiousness, Extraversion, Agreeableness, and Neuroticism). Despite the relevance of their findings in different countries, a shared limitation of such measures is their length, demanding time from researchers and participants, which might cause boredom or fatigue, biasing the final results. This research aimed to provide a shorter version for the 44-Item Big Five Inventory (BFI), through two studies $\left(\mathrm{N}_{\text {Total }}=8,119\right)$. The structure was assessed using a range of techniques (e.g., PAF analysis, Procrustes rotation). The best 20 items (4 per factor) were chosen to compose the final version of the BFI-20, which presented suitable psychometric evidences across the samples. Thus, due the growing need for shorter measures without losing their psychometric quality, our findings indicate the adequacy of the 20-item BFI and its potential applicability in research context.
\end{abstract}

Keywords personality; big five; bfi; short version

RESUMO

Várias medidas foram desenvolvidas nas últimas décadas para medir a personalidade, focando no Modelo dos Cinco Grandes Fatores (BFFM; Abertura, Conscienciosidade, Extroversão, Amabilidade e Neuroticismo). Apesar da relevância de suas descobertas em diferentes países, uma limitação de tais medidas é o seu tamanho, exigindo tempo de pesquisadores e participantes, o que pode causar tédio ou fadiga, influenciando os resultados. Esta pesquisa teve como objetivo fornecer uma versão mais curta para o Big Five Inventory (BFI), de 44 itens, através de dois estudos (NTotal =8.119). A estrutura foi analisada usando uma variedade de técnicas (por exemplo, PAF analysis, rotação de Procrustes). Os 20 melhores itens (4 por fator) foram escolhidos para compor a versão final do BFI-20, que apresentou evidências psicométricas adequadas nas amostras. Assim, devido à crescente necessidade de medidas mais curtas sem perder sua qualidade psicométrica, nossos resultados indicam a adequação do BFI de 20 itens e sua potencial aplicabilidade no contexto da pesquisa.

Palavras-chave personalidade; big five; bfi; psicometria

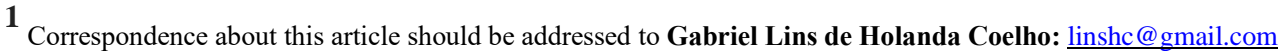

2 Conflicts of Interest: The authors declare that the research was conducted in the absence of any commercial or financial relationships that could be construed as a potential conflict of interest.
} 
Veloso Gouveia, Rodrigues araúJo, Vasconcelos de Oliveira, Pereira Gonçalves, Milfont, Lins de Holanda Coelho, SAntos, de Medeiros, Silva SoAres, Pereira Monteiro, Moura de Andrade, Medeiros CaValcanti, da Silva Nascimento, \& Gouveia

Uma versão curta do inventário dos cinco grandes fatores (BFI-20): evidências sobre a validade da construção

\section{Introduction}

Personality traits are stable characteristic patterns of thoughts, feelings and behaviors of each individual in their interaction with the environment (Dumont, 2010; Goldberg, 1993; Hall et al., 2000). The Big Five model is the most widely used taxonomy of personality traits. The Big Five model was developed from the lexical approach that uses trait-descriptive adjectives to identify the structure of personality traits. The model proposes the five trait factors of Openness to Experience, Conscientiousness, Extraversion, Agreeableness, and Neuroticism (Gurven et al., 2013; John et al., 2008; McCrae, 2011; Paunonen \& Jackson, 2000; Silva \& Nakano, 2011; Yarkoni, 2010; Wright, 2017).

Many psychometric measures have been developed to measure these five personality factors, comprising different sets of items and assessing directly the factors or their facets (e.g., Costa Jr. et al., 2001; Schmitt et al., 2007). However, most of the available measures comprise multiple items. When the inclusion of multiple measures is necessary in a particular research project or in occasions in which the researcher has limited time available for data collection, the length of the instruments becomes an issue. Hence, for certain research purposes long instruments are not desirable, as they cause fatigue and demotivation to the respondents, making it less likely for them to adhere to future studies (Credé et al., 2012). As an alternative for extensive instruments, some researchers have proposed and defended shorter measures of the Big Five factors, which has increased the number of brief versions for assessing these personality traits (e.g., Ames et al., 2006; Denissen et al., 2008; Gosling et al., 2003).

Despite the many advantages of shorter measures of the Big Five, it is important to note limitations. For instance, the instruments' reliability can be directly and negatively influenced by the small number of items (Carvalho et al., 2012), short measures might not represent the construct adequately (Clark \& Wilson, 1993; Yarkoni, 2010), and might lead to poor predictive validity (Credé et al., 2012). When proposing a shortened version for a personality measure, researchers should conciliate the length of the instrument with the quality of its psychometric parameters. In the current article, we present an effort to contribute with the measurement of personality, offering evidences on the construct 
validity (factorial validity and reliability) of a widely used measure for assessing the NEACO factors: the Big Five Inventory (Benet-Martínez \& John, 1998; Schmitt et al., 2007). This investigation beings with a brief overview of the

\section{The Big Five Factors: Characteristics and Measures}

The Big Five can be conceptualized as a hierarchical organization of personality traits, represented by specific traits clustered within facets which in turn are clustered within the five main personality dimensions, that indicate a structure in which most traits can be classified (McRae, 2010; McCrae \& John, 1992). The Big Five model is probably the most accepted model of personality in the literature given its replicability of the five factors in diverse and cross cultural samples (De Young et al., 2010; McCabe et al., 2013; Soto \& John, 2012). Despite the lack of consensus about the label for the Big Five factors (Silva \& Nakano, 2011), the core of its traits is similar in different approaches (Carvalho et al., 2012). Thus, each one of the factors is named based on a general trait, encompassing characteristics and semantics shared by the specific traits that form the corresponding dimension (Lima, 1997). As noted, the five general traits are Openness to Experience, Conscientiousness, Extraversion, Agreeableness and Neuroticism, which are often abbreviated in the OCEAN acronym. Based on available scholarship (De Young et al., 2010; Digman, 1990; Goldberg, 1993; McCrae, 1992), these broad personality traits can be summarized as follows. Openness to experience: Reflects the degree of intellectual curiosity, creativity, and a preference for novelty and variety; Conscientiousness: Indicates a tendency to show self-discipline, to act dutifully, and to aim for achievement; Extraversion: Energy, positive emotions, assertiveness, sociability, the tendency to seek for stimulation in the company of others, and talkativeness describe this trait; Agreeableness: Expresses a tendency to be compassionate and cooperative rather than suspicious and antagonistic towards others; and Neuroticism: Reflects the tendency to frequently experience unpleasant emotions, such as anger, anxiety, depression, or vulnerability.

The Big Five personality taxonomy has produced several benefits, including the ability to better integrate and compare findings from several studies (Parks \& Guay, 2009). The benefits of a widely accepted taxonomy of personality traits lead to the development of several rating instruments in the 1990's (Ostendorf \& Angleitner, 1994). Perhaps the most comprehensive instrument is Costa and McCrae's (1992) 240-item NEO 
Veloso gouveia, Rodrigues AraúJo, Vasconcelos de Oliveira, Pereira GonÇalves, Milfont, Lins de Holanda Coelho, SAntos, de Medeiros, Silva SoAres, Pereira Monteiro, Moura de Andrade, Medeiros CaValcanti, da Silva Nascimento, \& Gouveia

Personality Inventory (NEO-PI), which comprises six facet scales for each of the five factors and ca be completed in an average of $45 \mathrm{~min}$. Another also well-known measure is Goldberg's (1992) 100-item Trait Descriptive Adjectives (TDA), which also covers includes facet scales for the five main dimensions and requires around $15 \mathrm{~min}$ to be completed.

Both NEO-PI and TDA are excellent possibilities when clinicians or researchers have sufficient time to use them. Nevertheless, the everyday circumstances of research often demand the use of brief instruments with sufficient evidence of face validity and reliability. Distinct research situations require the availability of validated brief measures, including Internet-based studies, in large-scale surveys or in longitudinal studies when multiple questionnaires are used (Gosling et al., 2003). Consequently, shorter instruments have been proposed, ranging from 5 (Sporrle \& Bekk, 2013), to 10 (Gosling et al., 2003), 15 (Lang et al., 2011), 20 (O'Keefe et al., 2012), or 40 (Saucier, 1994) items. However, it is a great challenge to maintain the psychometric properties of an inventory with fewer items. For instance, in some cases, the Cronbach's alphas for the five dimensions are lower than the recommended (e.g., .40 for Agreeableness and .45 for Openness; Gosling et al., 2003). In the following, we discuss the Big Five Inventory, the measure used in the present research, with a focus on available brief measures.

\section{The Big Five Inventory}

Many instruments for assessing the Big Five model of personality have been developed based on the pool of items from Goldberg's (1992) 100-item TDA (see, e.g., Goldberg et al., 2006; Saucier, 1994). Among these measures, John et al.'s (1991) 44items Big Five Inventory (BFI) is one of the most used instruments in studies about personality and correlates, mainly due to its clear factorial structure, acceptable coefficients of reliability, and significant convergent validity (Soto \& John, 2009). Indeed, the BFI has been validated in more than 50 countries in all the inhabited continents, including Brazil, Japan, Lebanon, New Zealand, Poland, South Africa, United Kingdom, and United States (Schmitt et al., 2007). Some substantial evidence of its psychometric parameters are detailed below.

Factorial Validity. The factorial structure of the BFI has been explored in different social contexts and distinct methodological approaches, such as exploratory and 
confirmatory factor analyses (e.g., Atmoko, 2013; Benet-Martínez \& John, 1998; Fossati, Borroni et al., 2011; Gurven et al., 2013; John \& Srivastava, 1999; Leung et al., 2013; Marsh et al., 2010; Plaisant et al., 2010; Schmitt et al., 2007; van der Linde et al., 2010; Worrel \& Cross Jr., 2004). For instance, Plaisant et al. (2010) identified the expected five factors with exploratory factor analysis (principal components, Varimax rotation) is a sample of 2,499 French undergraduate students, which explained $42 \%$ of the total variance.

Convergent Validity. Examining convergent validity in the United States, Soto and John (2009) administered the BFI and the NEO-PI-R to 565 participants (undergraduate students and general population). The mean coefficients of correlation between the corresponding dimensions of personality traits in these instruments were higher than .70 in both groups, being stronger for undergraduate students $\left(r_{\text {average }}=.93\right.$ ) than for the general population $\left(r_{\text {average }}=.82\right)$. In their study, Plaisant et al. (2010) administered both the BFI and the NEO-PI-R to their French sample. The corresponding factors and facets correlated strongly with each other, ranging from .69 (Openness) to .82 (Conscientiousness). Finally, Fossati et al. (2011) administered the BFI and the NEOIPIP to three samples from the general population in Italy $\left(N_{\text {Total }}=1,041\right)$. Overall, results once again indicated mean correlations equal to or higher than .60 between the corresponding factors of these two instruments.

Reliability. In general, studies have focused on Cronbach's alpha as evidence of reliability, with supporting evidence in multiple cultures, such as Bolivia (Gurven et al., 2013), Canada (Srivastava et al., 2003), France (Paisant et al., 2010), Italy (Fossati et al., 2011), Spain (Benet-Martínez \& John, 1998), Turkey (Karaman et al., 2010), and the United States (Benet-Martínez \& John, 1998; John \& Srivastava, 1998; Srivastava et al., 2003). Overall the average Cronbach's alphas for each dimension of the BFI were all higher than .70, ranging from .73 (Neuroticism) to .81 (Extraversion)-except for the Bolivia study, which showed a mean coefficient of .55 [ranging from .31 (Openness) to .69 (Conscientiousness)]. Fossati et al. (2011) also checked evidence of temporal stability (test-retest; 2-month period) for the five factors of the BFI, observing correlation coefficients greater than .75 for all factors. 
Veloso gouveia, Rodrigues AraúJo, Vasconcelos de Oliveira, Pereira GonÇalves, Milfont, Lins de Holanda Coelho, SAntos, de Medeiros, Silva SoAres, Pereira Monteiro, Moura de Andrade, Medeiros Cavalcanti, da Silva Nascimento, \& Gouveia

Brief Measures of the Big Five Inventory

Many brief versions of the BFI have been proposed. Aiming to provide a psychometrically sound measure for contexts in which participant time is usually quite limited, Rammstedt and John (2007) abbreviated the Big Five Inventory to a 10-item version. Their results indicated that reducing the items yielded effect sizes that were lower than those for the full version-and the losses were more substantial for the Agreeableness scale — but still sufficient for research settings in which participant time is at a premium. Overall, results indicate that the 10-item version retain significant levels of reliability and validity. Similarly, Engvik and Clausen (2011) developed a 20-item Norwegian version of the Big Five Inventory. Although noting that it is impossible to measure something as comprehensive and complex as personality in an ideal way with just 20 test items, the authors concluded that their short version may be useful in several settings that do not require optimal measurement of personality, such as large-scale survey studies in the general population.

In another study, Hahn et al (2012) explored the psychometric characteristics of a 15-item version of the Big Five Inventory by comparing it with a reduced version of the NEO-PI in a German sample. Despite shortcomings for the Agreeableness factor, the short scales generally showed acceptable levels of internal consistency, stability over an 18-month period, convergent validity in relation to the NEO-PI, and discriminant validity. Another contribution was made by Soto and John (2017) who developed and validated both a 30 -item and a 15-item version. Across two studies, these authors observed that these brief versions respectively provide approximately $10 \%$ and $20 \%$ less reliability and validity than the full version of the scales. The authors concluded the use of the short versions are useful in research contexts where assessment time or respondent fatigue might be an issue.

In Brazil, Laros et al. (2018) examined convergent and factor validity of two Big Five measures, one with 20 items and another with 32 items (Andrade, 2008). The fivefactor model showed an adequate fit to the data after excluding several items. Moderate evidence of convergent validity was found for Extraversion, Neuroticism, and Openness to Experience (correlations corrected for attenuation between similar factors varied from .60 to .80). For Conscientiousness and Agreeableness, weaker evidence was found (correlations corrected for attenuation between similar factors varied from .43 to .48). The 
authors argued that the study did not present a representative sample of the entire Brazilian population, as data was obtained from 554 subjects in two Brazilian cities.

\section{The Present Research}

As reviewed above, the BFI has been used in diverse cultures, showing evidences of factorial and convergent validity, and reliability. However, despite its popularity and usefulness in the research context, the measure has an extensive number of items, which can be problematic when the demanded time is short and/or many constructs are assessed (Denissen et al., 2008; Rammsted \& John, 2007). The present research contributes to a growing literature developing or evaluating the psychometric parameters of brief measures to assess personality traits (Denissen et al., 2008; Gosling et al., 2003; Rammsted \& John, 2007; Sporrle \& Bekk, 2013; Woods \& Hampson, 2005) by examining the psychometric properties of the BFI across Brazilian samples.

In particular, this article reports two studies examining the psychometric properties of the BFI-44 in Brazil and the development of a short version of the scale. Study 1 examines the adequacy of the BFI-44 in a large sample of Brazilian participants considering parameters reported by Schmitt et al. (2007). Study 2 examines the factorial structure of the proposed 20-item version of the scale in another large Brazilian sample, checking its congruence regarding the previous study.

\section{Study 1}

\section{Method}

\section{Participants}

Participants were 4,995 Psychology/Education undergraduate students from all five Brazilian regions, covering 24 out of its 27 states (see Table 1). Most of the participants were women $(71 \%)$, single $(75.7 \%)$, with mean age of 23.7 years $(S D=6.99$, ranging from 16 to 67$)$. This was a non-probabilistic and convenience sample, including students who voluntarily agreed to participate. 
Veloso Gouveia, Rodrigues araúJo, Vasconcelos de Oliveira, Pereira Gonçalves, Milfont, Lins de Holanda Coelho, SAntos, de Medeiros, Silva Soares, Pereira Monteiro, Moura de Andrade, Medeiros CaValcanti, da Silva Nascimento, \& Gouveia

Table 1.

Participants' demographic characteristics and factorial congruence of the Big Five in Brazil

\begin{tabular}{|c|c|c|c|c|c|c|c|c|}
\hline \multirow{2}{*}{ Brazil's Regions and States } & \multirow{2}{*}{$\mathrm{N}$} & \multirow{2}{*}{$\%$ Female } & \multirow{2}{*}{ Mage (SD) } & \multicolumn{5}{|c|}{ Factorial Congruence } \\
\hline & & & & $\mathrm{O}$ & $\mathrm{C}$ & $\mathrm{E}$ & A & $\mathrm{N}$ \\
\hline North & 1.003 & 73.8 & $25.2(7.66)$ & .94 & .88 & .91 & .91 & .96 \\
\hline Acre & 141 & 46.8 & $19.7(4.64)$ & .91 & .87 & .87 & .92 & .83 \\
\hline Amazonas & 195 & 74.9 & $26.0(7.95)$ & .94 & .91 & .92 & .92 & .95 \\
\hline Rondônia & 208 & 81.9 & $25.8(8.22)$ & .93 & .86 & .90 & .92 & .90 \\
\hline Roraima & 229 & 70.5 & $28.0(7.55)$ & .85 & .86 & .88 & .87 & .92 \\
\hline Tocantins & 230 & 85.5 & $24.7(6.66)$ & .95 & .82 & .85 & .87 & .91 \\
\hline Northeast & 1.821 & 70.3 & $23.0(6.86)$ & .96 & .91 & .94 & .94 & .97 \\
\hline Alagoas & 171 & 83.0 & $24.4(5.66)$ & .93 & .88 & .88 & .91 & .90 \\
\hline Bahia & 155 & 60.6 & $17.5(2.71)$ & .91 & .78 & .90 & .90 & .89 \\
\hline Ceará & 205 & 80.3 & $23.6(7.19)$ & .95 & .88 & .88 & .90 & .94 \\
\hline Maranhão & 200 & 64.6 & $25.8(7.02)$ & .89 & .76 & .86 & .89 & .85 \\
\hline Paraíba & 209 & 68.9 & $20.3(3.92)$ & .91 & .73 & .90 & .87 & .90 \\
\hline Pernambuco & 223 & 67.6 & $24.8(7.92)$ & .94 & .89 & .92 & .90 & .95 \\
\hline Piauí & 246 & 70.9 & $26.1(8.49)$ & .91 & .86 & .93 & .94 & .95 \\
\hline Rio Grande do Norte & 196 & 70.8 & $22.8(5.99)$ & .94 & .88 & .91 & .91 & .96 \\
\hline Sergipe & 216 & 66.0 & $20.0(4.18)$ & .93 & .72 & .90 & .89 & .88 \\
\hline Centre-West & 826 & 73.1 & $23.1(6.61)$ & .96 & .90 & .91 & .91 & .96 \\
\hline Distrito Federal & 207 & 53.1 & $22.3(4.52)$ & .92 & .85 & .91 & .91 & .93 \\
\hline Goiás & 227 & 70.7 & $24.1(7.76)$ & .93 & .91 & .91 & .88 & .95 \\
\hline Mato Grosso & 201 & 87.0 & $23.7(6.72)$ & .95 & .84 & .89 & .86 & .91 \\
\hline Mato Grosso do Sul & 191 & 83.2 & $22.3(6.76)$ & .93 & .81 & .84 & .88 & .93 \\
\hline Southeast & 950 & 67.2 & $24.5(6.83)$ & .96 & .93 & .94 & .93 & .95 \\
\hline Espirito Santo & 152 & 49.0 & $22.7(6.63)$ & .90 & .87 & .73 & .85 & .89 \\
\hline Minas Gerais & 348 & 72.1 & $23.3(4.74)$ & .95 & .88 & .93 & .94 & .97 \\
\hline Rio de Janeiro & 245 & 55.1 & $25.5(7.08)$ & .93 & .90 & .91 & .89 & .93 \\
\hline São Paulo & 205 & 86.7 & $26.7(8.69)$ & .93 & .86 & .88 & .89 & .85 \\
\hline South & 395 & 70.8 & $22.1(5.91)$ & .96 & .91 & .93 & .94 & .95 \\
\hline Rio Grande do Sul & 179 & 85.4 & $23.3(6.15)$ & .93 & .87 & .89 & .91 & .95 \\
\hline Santa Catarina & 216 & 58.8 & $21.0(5.52)$ & .93 & .90 & .91 & .93 & .83 \\
\hline
\end{tabular}

\section{Instruments and Procedure}

This study was part of a larger national project examining the personality correlates of basic human values. Participants received a survey booklet with the Basic Values Survey (Gouveia et al., 2015) and the BFI-44 (John \& Srivastava, 1999), plus demographic questions (age, sex, marital status, and religiosity degree). The survey package was sent by post to research collaborators in each state, who were asked to administer the survey in class to their students who were 18 years old or older. The project followed ethics guidelines from the National Health Council in Brazil (resolution 466/12), and obtained ethics approval from the Federal University of Paraiba (approval number: 06043712.2.00005188).

Only the BFI-44 was considered in the present analyses, which comprises items covering all five personality factors: Openness (e.g., Is inventive; Is ingenious, a deep 
thinker), Conscientiousness (e.g., Does things efficiently; Perseveres until the task is finished), Extraversion (e.g., Is talkative; Is full of energy), Agreeableness (e.g., Has a forgiving nature; Is helpful and unselfish with others), and Neuroticism (e.g., Is depressed, blue; Gets nervous easily). Participants indicated the extent to which each item described them on a 5-point Likert scale, ranging from 1 (Disagree strongly) to 5 (Agree strongly). The average completion time for the questionnaires was 15 minutes. The translation of the BFI from its English version into the Portuguese-Brazilian version was produced using the committee approach (Brislin, 1970) by three bilingual psychologists.

\section{Data Analysis}

Using SPSS (version 21), the raw responses of the BFI were factored using principal axis factoring (PAF, Varimax rotation). We used Procrustes rotation to check the factorial congruence of the Brazilian matrix to the Schmitt et al.'s (2007) structure, using the syntax provided by McCrae et al. (1996). The choice of Schmitt et al.'s structure as a target for the Procrustes rotation was based on the fact that it represents a wide crosscultural sample (56 nations), including Brazilian participants, serving as the standard for the BFI factorial structure. We then used Cronbach's alpha to assess the internal consistency of the five factors.

\section{Results}

We first carried out a PAF analysis followed by a parallel analysis to identify the number of factors to extract across the full sample. Although the parallel analysis suggested up to eight factors, five clear factors with eigenvalues greater than 2 were observed, accounting for $35.7 \%$ of the total variance. Table 2 presents the factor structure of the BFI, and inspection indicates that the structure is similar to the one reported by Schmitt et al. (2007). 
Veloso gouveia, Rodrigues Araújo, Vasconcelos de Oliveira, Pereira GonÇalves, Milfont, Lins de Holanda Coelho, SAntos, de Medeiros, Silva Soares, Pereira Monteiro, Moura de Andrade, Medeiros Cavalcanti, da Silva Nascimento, \& Gouveia

Table 2.

Factor loadings for the BFI after Procruste Rotation Targeted to the Schmitt et al. 's

Normative

\begin{tabular}{|c|c|c|c|c|c|}
\hline \multicolumn{6}{|l|}{ Structure } \\
\hline English version of the BFI Items* & $\mathrm{E}$ & A & $\mathrm{C}$ & $\mathrm{N}$ & $\mathrm{O}$ \\
\hline Is talkative & .60 & .08 & -.01 & .03 & .13 \\
\hline Is outgoing, sociable & .66 & .17 & .03 & -.03 & .19 \\
\hline Generates a lot of enthusiasm & .40 & .13 & .12 & .09 & .34 \\
\hline Is full of energy & .37 & .15 & .19 & -.06 & .27 \\
\hline Has an assertive personality & .31 & -.01 & .13 & -.04 & .16 \\
\hline Tends to be quiet & -.76 & .08 & .05 & .06 & .07 \\
\hline Is shy, inhibited & -.50 & .16 & -.11 & .17 & .10 \\
\hline Is reserved & -.54 & .02 & .13 & .05 & .15 \\
\hline Is considerate and kind to almost everyone & .07 & .56 & .09 & .04 & .16 \\
\hline Has a forgiving nature & .09 & .35 & .01 & -.08 & .08 \\
\hline Is helpful and unselfish with others & .11 & .65 & .15 & .09 & .15 \\
\hline Likes to cooperate with others & .09 & .61 & .13 & .08 & .15 \\
\hline Is generally trusting & .02 & .20 & .15 & .01 & .10 \\
\hline Is sometimes rude to others & .04 & -.28 & -.16 & .39 & .10 \\
\hline Starts quarrels with others & .20 & -.30 & -.07 & .17 & .19 \\
\hline Can be cold and aloof & -.18 & -.27 & -.16 & .19 & .14 \\
\hline Tends to find fault in others & .10 & -.29 & -.02 & .16 & .15 \\
\hline Does a thorough job & -.02 & -.03 & .45 & .09 & .20 \\
\hline Does things efficiently & .09 & .14 & .42 & .00 & .24 \\
\hline Perseveres until the task is finished & .09 & .14 & .44 & -.02 & .18 \\
\hline Is a reliable worker & .04 & .25 & .32 & .05 & .10 \\
\hline Makes plans, follows through with them & .05 & .13 & .37 & .03 & .20 \\
\hline Tends to be lazy & -.07 & -.10 & -.55 & .16 & .10 \\
\hline Tends to be disorganized & .03 & -.04 & .52 & .10 & .12 \\
\hline Can be somewhat careless & -.03 & .05 & -.54 & .17 & .22 \\
\hline Is easily distracted & -.11 & .02 & -.45 & .14 & .11 \\
\hline Worries a lot & -.03 & .18 & .22 & .40 & .10 \\
\hline Gets nervous easily & .06 & -.19 & -.04 & .72 & .00 \\
\hline Can be tense & -.03 & -.13 & -.01 & .69 & .01 \\
\hline Can be moody & -.01 & -.22 & -.10 & .48 & .08 \\
\hline Is depressed, blue & -.28 & -.16 & -.09 & .38 & .04 \\
\hline Is relaxed, handles stress well & -.04 & .12 & -.14 & -.44 & .25 \\
\hline Is emotionally stable, not easily upset & -.06 & .22 & .10 & -.49 & .14 \\
\hline Remains calm in tense situations & -.07 & .12 & .04 & -.45 & .24 \\
\hline
\end{tabular}




\begin{tabular}{lccccc} 
Is inventive & .23 & -.03 & .18 & -.09 & $\mathbf{. 5 6}$ \\
Has an active imagination & .12 & -.05 & .03 & .05 & $\mathbf{. 4 1}$ \\
Is original, has new ideas & .26 & .09 & .21 & -.08 & $\mathbf{. 5 2}$ \\
Likes to reflect, play with ideas & .08 & .06 & .04 & -.05 & $\mathbf{. 4 5}$ \\
Values artistic, aesthetic experiences & -.04 & .04 & .07 & -.01 & $\mathbf{. 3 3}$ \\
Is ingenious, deep thinker & .00 & -.02 & .25 & .06 & $\mathbf{. 4 4}$ \\
Is sophisticated in art, music, or literature & -.01 & .00 & .08 & -.11 & $\mathbf{. 3 6}$ \\
Is curious about many different things & .14 & .02 & .10 & .01 & $\mathbf{. 3 9}$ \\
Has few artistic interests & -.14 & .06 & -.01 & .13 & -.24 \\
Prefers work that is routine & -.17 & .02 & .00 & .02 & -.07 \\
\hline Factor Congruence & .97 & .93 & .94 & .94 & .97
\end{tabular}

Note: $E=$ Extraversion $; A=$ Agreeableness; $C=$ Conscientiousness $; N=$ Neuroticism $; O=$ Openness. Loadings higher than absolute .30 are reported in bold. * The Portuguese-Brazilian version of this instrument is available upon request.

To confirm the similarity in the factor structure formally, we computed the factorial congruence between our Brazilian data and the original factor structure observed in Schmitt et al. The results indicated good factor congruence coefficients for all five factors, ranging from .93 (Agreeableness) to .97 (Openness and Extraversion; see Table 2). Moreover, all factor loadings were equal to or greater than .30 in their corresponding factors, except for four Agreeableness items and two Openness items. Cronbach's alphas were also acceptable for all factors, excepting for Conscientiousness, as following: .69 (Openness), .56 (Conscientiousness), .72 (Extraversion), .69 (Agreeableness), and .69 (Neuroticism).

After examining the factorial congruence of the $B F I$ for the whole sample, we examined the factorial congruence considering Brazilian regions and states. As shown in Table 1, factorial congruence was also supported when considering the Brazilian regions/states. The coefficients of factorial congruence were higher for Openness (ranging from .94 to .96) and Neuroticism (ranging from .95 to .97), and lower for Conscientiousness (ranging from .88 to .93) and Agreeableness (ranging from .91 to .94). Some fluctuations regarding specific Brazilian states were also observed. For example, the Big Five factors were least well-represented in samples from Roraima and Maranhão, where the factorial congruency coefficients were often below the recommended cutoff point of .90 .

Overall, the results provide evidence for the five-factor structure of the $B F I$ in a large Brazilian sample as well as in the specific regions and states. However, some 
Veloso gouveia, Rodrigues AraúJo, Vasconcelos de Oliveira, Pereira GonÇalves, Milfont, Lins de Holanda Coelho, SAntos, de Medeiros, Silva Soares, Pereira Monteiro, Moura de Andrade, Medeiros Cavalcanti, da Silva Nascimento, \& Gouveia

specific items did not work adequately as reflected by low Cronbach's alphas, which were lower than those observed in the Schmitt et al. study. We conducted a new study to confirm the five-factor structure of the BFI-44 in Brazil and generate a more concise and reliable short version.

\section{Study 2}

\section{Method}

\section{Participants}

Participants in Study 2 comprise a distinct sample of 3,124 individuals from the Northeast of Brazil (Capitals, $n=1,541$; countryside cities, $n=1,583$ ). Most of the participants were women (63.8\%), single (78\%), with mean age of 23.6 years $(S D=6.71$; ranging from 18 to 73) (see Table 3). As in Study 1, this was a non-probabilistic and convenience sample of undergraduate students who completed the measures voluntarily. Table 3

Participants' demographic characteristics and factorial congruence of the Big Five in Northeast of Brazil

\begin{tabular}{|c|c|c|c|c|c|c|c|c|}
\hline \multirow{2}{*}{$\begin{array}{l}\text { Brazilian Northeast's } \\
\text { States }\end{array}$} & \multirow{2}{*}{$\mathrm{N}$} & \multirow{2}{*}{$\begin{array}{l}\% \\
\text { Female }\end{array}$} & \multirow{2}{*}{$\begin{array}{l}\text { Mage } \\
(\mathrm{SD})\end{array}$} & \multicolumn{5}{|c|}{ Factorial Congruence } \\
\hline & & & & $\mathrm{O}$ & $\mathrm{C}$ & $\mathrm{E}$ & A & $\mathrm{N}$ \\
\hline Northeast region & 3,124 & 63.8 & $23.6(6.71)$ & .92 & .85 & .85 & .90 & .85 \\
\hline Alagoas & 332 & 72.8 & $21.5(3.91)$ & .90 & .87 & .80 & .89 & .83 \\
\hline Bahia & 313 & 75.0 & $25.8(7.97)$ & .89 & .89 & .83 & .90 & .79 \\
\hline Ceará & 377 & 53.3 & $22.9(6.53)$ & .89 & .86 & .86 & .89 & .86 \\
\hline Maranhão & 336 & 54.3 & $25.9(8.73)$ & .91 & .73 & .85 & .86 & .80 \\
\hline Paraíba & 398 & 76.8 & $24.0(6.13)$ & .90 & .73 & .84 & .78 & .48 \\
\hline Pernambuco & 352 & 61.7 & $26.1(8.18)$ & .93 & .83 & .84 & .87 & .85 \\
\hline Piauí & 344 & 67.6 & $22.0(5.29)$ & .89 & .76 & .85 & .86 & .82 \\
\hline Rio Grande do Norte & 313 & 64.9 & $22.3(5.71)$ & .92 & .89 & .86 & .89 & .87 \\
\hline Sergipe & 359 & 48.5 & $22.1(4.39)$ & .89 & .83 & .84 & .88 & .83 \\
\hline Capitals & 1,541 & 65.5 & $23.9(7.44)$ & .92 & .88 & .83 & .91 & .87 \\
\hline Countryside cities & 1,583 & 62.1 & $23.3(5.90)$ & .91 & .80 & .85 & .88 & .81 \\
\hline
\end{tabular}

\section{Instrument, Procedure and Data Analysis}

This study is part of the same larger project investigating the personality correlates of human values in Brazil, but with a particular focus on the Northeast region of the country. Similar to Study 1, the survey package was posted to research collaborators, who collected data from their students during class time. The project followed ethics guidelines from the National Health Council in Brazil (resolution 466/12), and obtained 
ethics approval from the Federal University of Paraiba (approval number: CEP/HULW 257/10).

The survey questionnaire had the same measures as in Study 1, and the average completion time for the questionnaires was 15 minutes. To provide evidence of discriminant validity, we examined the values measure in this study which is composed of 18 marker values rated as guiding principles on a 7-point scale ranging from 1 (completely unimportant) to 7 (of the utmost importance). Gouveia (2003) argues there are six clusters of values based on their function of expressing basic needs and guiding behavior. Although using the BFI-44, our analysis focused on the best 20 items identified in the first study. We used a similar data analytical approach using Procrustes rotation to test the factorial congruence of the Northeastern matrix of the BFI-20 in relation to the national data from the first study. Cronbach's alphas $(\alpha)$ and McDonald's Omega $(\omega)$ for each factor were also computed. In addition, convergent validity between the BFI-20 and the BVS were calculated (Pearson's correlations).

\section{Results}

The PAF analysis resulted into five clear factors with eigenvalues greater than 1 and accounted for $37.2 \%$ of the total variance. The Northeastern factor structure of the BFI was similar to the one presented in Study 1. The factorial structure of the BFI-20 is presented in Table 4, corresponding to the second column of each factor. As expected, the factor loadings of all the items were higher than $|.30|$ in their respective theoretical factor. The lowest loadings (.31 for both) were for items 19 (Agreeableness) and 13 (Conscientiousness), and the highest were for items $16(.80$; Neuroticism) and 8 (.78; Agreeableness). The last five columns of the Table 3 present the factorial congruence coefficients, which ranged from acceptable (.85 for Conscientiousness, Extraversion, and Neuroticism) to good (at least .90 for Openness and Agreeableness). Overall, the largest congruence coefficients were observed on samples from capitals rather than countryside cities (results available upon request). 
Veloso gouveia, Rodrigues AraúJo, Vasconcelos de Oliveira, Pereira GonÇalves, Milfont, Lins de Holanda Coelho, SAntos, de Medeiros, Silva SoAres, Pereira Monteiro, Moura de Andrade, Medeiros CaValcanti, da Silva Nascimento, \& Gouveia

Table 4

Factor Structure of the 20-Items Big Five Inventory

\begin{tabular}{lllllllllll} 
Item / Factor & $\mathrm{I}$ & & $\mathrm{II}$ & & $\mathrm{III}$ & & $\mathrm{IV}$ & & $\mathrm{V}$ & \\
\hline 08 / A & .76 & .78 & .09 & -.02 & -.01 & .09 & .07 & .09 & .12 & .13 \\
$04 / \mathrm{A}$ & .71 & .70 & .12 & -.02 & -.03 & .05 & .05 & .09 & .10 & .09 \\
$09 / \mathrm{A}$ & .52 & .55 & .05 & -.04 & -.05 & .16 & .13 & .09 & .16 & .16 \\
19 / A & .28 & .31 & .02 & -.08 & -.09 & .07 & .14 & .09 & .07 & .03 \\
$05 / \mathrm{O}$ & .00 & .04 & .76 & -.06 & -.04 & .11 & .15 & .56 & .17 & .14 \\
$07 / \mathrm{O}$ & .14 & .17 & .67 & -.08 & -.05 & .19 & .16 & .56 & .18 & .24 \\
14 / O & .01 & .03 & .40 & .14 & .09 & .09 & .11 & .46 & .04 & .04 \\
$18 / \mathrm{O}$ & .11 & .14 & .31 & .04 & -.03 & .10 & .13 & .40 & .10 & .03 \\
$16 / \mathrm{N}$ & -.10 & -.09 & -.03 & .80 & .79 & .03 & .04 & .00 & -.01 & .01 \\
$15 / \mathrm{N}$ & -.03 & -.03 & -.02 & .74 & .74 & -.03 & -.03 & .04 & -.01 & -.02 \\
$06 / \mathrm{N}$ & -.11 & -.17 & .06 & .52 & .45 & -.05 & -.03 & .05 & -.06 & -.02 \\
$20 / \mathrm{N}$ & .19 & .23 & -.00 & .37 & .35 & -.01 & .03 & .01 & .27 & .24 \\
$11 / \mathrm{E}$ & .14 & .18 & .16 & -.06 & -.04 & .77 & .75 & .12 & .02 & .08 \\
$01 / \mathrm{E}$ & .10 & .08 & .14 & -.03 & .02 & .65 & .59 & .14 & .00 & .06 \\
17 / E & .12 & .11 & .29 & .14 & .09 & .44 & .45 & .29 & .16 & .13 \\
12 / E & .12 & .12 & .23 & -.10 & -.07 & .43 & .41 & .25 & .26 & .24 \\
$10 / \mathrm{C}$ & .12 & .21 & .17 & -.04 & -.03 & .15 & .10 & .11 & .53 & .53 \\
$03 / \mathrm{C}$ & .13 & .14 & .11 & -.01 & -.05 & .12 & .07 & .09 & .52 & .50 \\
$02 / \mathrm{C}$ & .00 & -.02 & .14 & .08 & .07 & -.01 & -.02 & .11 & .47 & .48 \\
$13 / \mathrm{C}$ & .21 & .28 & .03 & -.01 & -.01 & .13 & .07 & .06 & .37 & .31 \\
\hline
\end{tabular}

The Cronbach's alpha and McDonald's Omega coefficients for the BFI-20 scales for the whole Northeast samples were $.72(\alpha)-.73(\omega)$ (Extraversion), .69 $(\alpha)-.64(\omega)$ (Agreeableness), .56 $(\alpha)-.55(\omega)$ (Conscientiousness), .69 $(\alpha)-.72(\omega)$ (Neuroticism), and .60 $(\alpha)$-.61 $(\omega)$ (Openness). In comparison with Study 1, Conscientiousness, Neuroticism and Openness had lower reliability, while Agreeableness and Extraversion had higher internal consistency.

To provide convergent validity evidence for the BFI-20 we used the Basic Value Survey. The results are shown in Table 5. As expected, the BFI-20 presented statistically significant correlations with certain basic values and broadly align with previous work examining traits-values links (Roccas et al., 2002). While Extraversion correlated positively with all basic values, Openness seems to find stronger correspondence with values emphasizing a focus on personal goals, aesthetics, cognition and interpersonal relationships (i.e., excitement, suprapersonal, interactive and promotion values). While Openness correlated positively with all basic values except normative, Conscientiousness correlated positively with all except excitement. Stronger discriminant validity was observed for Agreeableness, which correlated positively with suprapersonal, interactive, existence and normative while negatively with excitement and promotion. Similar to 
previous findings (Roccas et al., 2002), Neuroticism did not show reliable associations with basic values.

Table 5.

Correlations Between Personality Traits and Human Values

\begin{tabular}{llllll}
\hline & $\mathrm{O}$ & $\mathrm{C}$ & $\mathrm{E}$ & $\mathrm{A}$ & $\mathrm{N}$ \\
\hline Excitement & $.14^{* *}$ & .01 & $.14^{*}$ & $-.12^{* *}$ & .01 \\
Suprapersonal & $.34^{* *}$ & $.14^{* *}$ & $.12^{* *}$ & $.08^{* *}$ & -02 \\
Interactive & $.10^{* *}$ & $.12^{* *}$ & $.16^{* *}$ & $.25^{* *}$ & -.02 \\
Promotion & $.14^{* *}$ & $.13^{* *}$ & $.14^{* *}$ & $-.11^{* *}$ & .01 \\
Existence & .03 & $.23^{* *}$ & $.10^{* *}$ & $.09^{* *}$ & -02 \\
Normative & -.03 & $.28^{* *}$ & $.16^{* *}$ & $.29^{* *}$ & -.01 \\
\hline Note: ${ }^{*}<<.05 .{ }^{* *} p<.01$. O $=$ Openness; C $=$ Conscientiousness $;$ E Extraversion; A $=$ Agreeableness; \\
$N=$ Neuroticism
\end{tabular}

\section{Discussion}

There are many taxonomies of personality traits, including Eysenck's three-factor model and Cattell's sixteen-factor model (Barbaranelli \& Caprara, 1996; Eysenck, 1991). The Big Five model is the most widely used taxonomy suggesting Openness to Experience, Conscientiousness, Extraversion, Agreeableness and Neuroticism as the core general factors of personality traits (e.g, Gurven et al., 2013; John et al., 2008; McCrae, 2011; Wright, 2017). As a result, many instruments have been developed over the years to measure these personality factors, many of them using larger set of items (e.g., Costa \& McCrae, 1992; Goldberg, 1992). However, knowing the limitations of having a measure that demands lots of time from participants, resulting in problems as fatigue and boredom, efforts to develop shorter versions have also been carried out (e.g., Lang et al., 2011; O'Keefe et al., 2012). The current study contributed to this literature by examining the psychometric properties and a brief version the Big Five Inventory (BFI), which is one the most used instruments, in large samples from all Brazilian regions $\left(N_{\text {Total }}=8,119\right)$.

Findings from Study 1 indicated the five-factor structure replicated well in Brazil, as indicated by eigenvalues and parallel analysis results. This was confirmed by good coefficients of factorial congruence (e.g., higher than .90) when comparing the observed factor structure in our Brazilian sample with the factor structure reported by Schmitt et al.'s (2007) study with cross-cultural samples. All five factors also had acceptable reliability for applied research purposes (Cronbach's alphas close to .70; Clark \& Watson, 1995), except for Conscientiousness. In Study 2 we consider the items with best factor loadings in the first study to propose a 20-item version of the BFI, comprising four items 
Veloso gouveia, Rodrigues Araújo, Vasconcelos de Oliveira, Pereira Gonçalves, Milfont, Lins de Holanda Coelho, SAntos, de Medeiros, Silva SoAres, Pereira Monteiro, Moura de Andrade, Medeiros Cavalcanti, da Silva Nascimento, \& Gouveia for each of the five factors. This BFI-20 showed adequate psychometric properties, as evidenced by high coefficients of factorial congruence comparing its loadings with those obtained in Study 1 . The scales also showed good internal reliability, as evidenced by both alpha and omega coefficients. Indeed, the Cronbach's alphas for its five factors were in line with previous studies and the literature (e.g., Benet-Martínez \& John, 1998; Fossati et al., 2011; Srivastava et al., 2003). Discriminant validity was also confirmed by correlations between the five personality factors and six basic values. To illustrate, while Extroversion was positively and statistically correlated with all basic values, Neuroticism had no reliable correlations with value. This finding replicated those reported by Roccas et al. (2002), who also observed no reliable association between Extroversion and values is a sample of Israeli university students - only one Extroversion facet (Angry hostility) correlated negatively with benevolent values.

According to our results, the 20-item version of the Big Five Inventory (or BFI20) can be adequately used as a measure of the basic five factors of the personality for research proposes in Brazil. Despite being expected that Cronbach's alpha will be negatively affected by the reduction of items (Yuan \& Bentler, 2002), even after eliminating up to $50 \%$ of the items, this most commonly used coefficient (Dunn et al., 2014) had similar or better results than the those found for the 44-item in Schmitt et al. (2007), and mainly for Conscientiousness in Study 1. Perhaps Conscientiousness is a broader construct, involving more than one idea in the Brazilian context, comprehending both a way of behaving (e.g., "Does things efficiently"; "Perseveres until the task is finished") and a personal characteristic (e.g., "Does a thorough job"; "Is a reliable worker").

Notwithstanding the evidences of adequacy of the BFI-20, potential limitations of the studies can be pointed out. Firstly, the sampling comprised participants who are literate and urban, although we made an intent to include people from the countryside in Study 2, a less common practice in studies on personality traits (Gurven et al., 2013). For the current version, besides showing adequate psychometric parameters (evidences on factorial validity and reliability), its five subscales or factors were composed only by positive items, which can induce response bias (van Sonderen et al., 2013). Moreover, when a set of items is reduced, it is possible that it will be less able to cover the full range of a construct. However, a set of four items by factor is in line with the recommended by the literature (Hair et al., 2010). 
Finally, future studies must be carried out to check the additional psychometric evidences of the BFI-20 in Brazil, as well as to test whether the same set of 20 items that adequately index the Big Five in Brazil would showed similar adequacy in other cultural contexts; including those using similar language (Portugal and Angola) and other languages with and without cultural similarities (e.g., Argentina, Finland). Furthermore, it will be important to assess the adequacy of its set of items by the Items Response Theory, exploring their functionality individually and in the pool. Regarding the inventory itself, it is important to observe its convergent validity to alternative measures of the Big Five, including shortened ones, such as the Ten-Item Personality Inventory (Gosling et al., 2003). Furthermore, it is necessary to investigate any potential response bias altering participants' scores, as social desirability (discriminant validity), as well as to estimate the predictive power (predictive validity) of the brief version. Checking its temporal stability (test-retest) is equally important, assuring its usability in longitudinal studies, for instance. 
Veloso gouveia, Rodrigues AraúJo, Vasconcelos de Oliveira, Pereira GonÇalves, Milfont, Lins de Holanda Coelho, SAntos, de Medeiros, Silva SoAres, Pereira Monteiro, Moura de Andrade, Medeiros Cavalcanti, da Silva Nascimento, \& Gouveia

\section{References}

Ames, D. R., Rose, P., \& Anderson, C. P. (2006). The NPI-16 as a short measure of narcissism. Journal of Research in Personality, 40, 440-450. https://doi.org/10.1016/j.jrp.2005.03.002

Andrade, J. M. de (2008). Evidências de validade do inventário dos cinco grandes fatores de personalidade para o Brasil. Unpublished doctoral thesis. Brasília: University of Brasilia, Brazil.

Atmoko, D. D. (2013). Testing construct validity of the Big Five Inventory (Indonesian adaptation) using confirmatory factor analysis. https://ssrn.com/abstract $=2242747$

Barbaranelli, C., \& Caprara, G. V. (1996). How many dimensions to describe personality? A comparison of Cattell, Comrey, and the big five taxonomies of personality traits. European Review of Applied Psychology, 46(1), 15-24. https://psycnet.apa.org/record/1998-11586-002

Benet-Martínez, V., \& John, O. P. (1998). Los cinco grandes across cultures and ethnic groups: Multitrait multimethod analysis of the Big Five in Spanish and English. Journal of Personality and Social Psychology, 75, 729-750. https://psycnet.apa.org/buy/1998-12057-011

Brislin R. W. (1970). Back- translation for cross- cultural research. Journal of Cross-Cultural Psychology, 1, 185-216. https://doi.org/10.1177/135910457000100301

Carvalho, L. F., Nunes, M. F. O., Primi, R., \& Nunes, C. H. S. S. (2012). Unfavorable evidence for personality assessment with a 10 -item instrument. Paidéia, 22(51), 63-71. https://dx.doi.org/10.1590/S0103$\underline{863 X 2012000100008}$

Clark, L. A., \& Watson, D. (1995). Constructing validity: Basic issues in objective scale development. Psychological Assessment, 7, 309-319. https://doi.org/10.1037/14805-012

Costa, P. T., \& McCrae, R. R. (1992). NEO PI-R professional manual. Odessa, FL: Psychological Assessment Resources.

Costa Jr, P., Terracciano, A., \& McCrae, R. R. (2001). Gender differences in personality traits across cultures: robust and surprising findings. Journal of Personality and Social Psychology, 81, 322-331. https://doi.org/10.1037/0022-3514.81.2.322

Credé, M., Harms, P., Niehorster, S., \& Gaye-Valentine, A. (2012). An evaluation of the consequences of using short measures of the Big Five personality traits. Journal of Personality and Social Psychology, 102, 874-888. http://dx.doi.org/10.1037/a0027403

Denissen, J. J., Geenen, R., Selfhout, M., \& Van Aken, M. A. (2008). Single- item Big Five ratings in a social network design. European Journal of Personality, 22, 37-54. https://doi.org/10.1002/per.662

De Young, C. G., Hirsh, J. B., Shane, M. S., Papademetris, X., Rajeevan, N., \& Gray, J. R. (2010). Testing predictions from personality neuroscience brain structure and the Big Five. Psychological Science, 21, 820-828. https://doi.org/10.1177/0956797610370159

Digman, J. M. (1990). Personality structure: Emergence of the five-factor model. Annual Review of Psychology, 41, 417-440. https://doi.org/10.1146/annurev.ps.41.020190.002221 
Dumont, F. (2010). A history of personality psychology: Theory, science, and research from Hellenism to the twenty-first century. Cambridge University Press.

Dunn, T. J., Baguley, T., \& Brunsden, V. (2014). From alpha to omega: A practical solution to the pervasive problem of internal consistency estimation. British journal of psychology, 105(3), 399-412. https://doi.org/10.1111/bjop.12046

Engvik, H. \& Clausen, S. E. (2011). Norsk kortversjon av big five inventory (BFI20). Tidsskr Nor Psyk, 48, 869-872. https://www.researchgate.net/publication/285633293

Eysenck, H. J. (1991). Dimensions of personality: 16, 5 or 3 ? - Criteria for a taxonomic paradigm. Personality and Individual Differences, 12 (8), 773790. https://doi.org/10.1016/0191-8869(91)90144-Z

Fossati, A., Borroni, S., Marchione, D., \& Maffei, C. (2011). The Big Five Inventory (BFI). European Journal of Psychological Assessment, 27, 50-58. https://doi.org/10.1027/1015-5759/a000043

Goldberg, L. R. (1992). The development of markers for the Big Five factor structure. Psychological Assessment, 4, 26-42. https://doi.org/10.1037/10403590.4.1.26

Goldberg, L. R. (1993). The structure of phenotypic personality traits. American Psychologist, 48, 26-34. https://doi.org/10.1037/0003-066X.48.1.26

Goldberg, L. R., Johnson, J. A., Eber, H. W., Hogan, R., Ashton, M. C., Cloninger, C. R., \& Gough, H. G. (2006). The international personality item pool and the future of public-domain personality measures. Journal of Research in Personality, 40, 84-96. https://doi.org/10.1016/j.jrp.2005.08.007

Gosling, S. D., Rentfrow, P. J., \& Swann Jr, W. B. (2003). A very brief measure of the big-five personality domains. Journal of Research in Personality, 37, 504-528. https://doi.org/10.1016/S0092-6566(03)00046-1

Gouveia, V. V., Milfont, T. L., Vione, K. C., \& Santos, W. S. (2015). Guiding actions and expressing needs: On the psychological functions of values. Psykhe, 24(2), 1-14. https://doi.org/10.7764/psykhe.24.2.884

Gurven, M., von Rueden, C., Kaplan, H., \& Lero Vie, M. (2013). How universal is the Big Five? Testing the five-factor model of personality variation among forager-farmers in the Bolivian Amazon. Journal of Personality and Social Psychology, 104 (2), 354-370. https://doi.org/10.1037/a0030841

Hair, J.F., Black, W.C., Babin, B.J., \& Anderson, R.E. (2010). Multivariate data analysis $\left(7^{\text {th }}\right.$ Ed.). Pearson.

Hall, C. S., Lindzey, G., \& Campbell, J. B. (2000). Teorias da personalidade [Theories of perssonality]. Artmed.

Hah, E., Gottschling, J., \& Spinath, F. M. (2012). Short measurements of personality - Validity and reliability of the GSOEP Big Five Inventory (BFI-S). Journal of Research in Personality, 46, 355-359. http://dx.doi.org/10.1016/j.jrp.2012.03.008

John, O. P., Donahue, E. M., \& Kentle, R. L. (1991). The Big Five Inventory Versions 4a and 54. University of California, Berkeley, Institute of Personality and Social Research.

John, O. P., Naumann, L. P., \& Soto, C. J. (2008). Paradigm shift to the integrative big five trait taxonomy: History, measurement, and conceptual issues. In O. P. John, R. W. Robins, \& L. A. Pervin (Eds.), Handbook of personality: Theory and research (3rd ed., pp. 114-158). Guilford. 
Veloso gouveia, Rodrigues AraúJo, Vasconcelos de Oliveira, Pereira GonÇalves, Milfont, Lins de Holanda Coelho, SAntos, de Medeiros, Silva SoAres, Pereira Monteiro, Moura de ANdrade, Medeiros Cavalcanti, da Silva Nascimento, \& Gouveia

John, O. P., \& Srivastava, S. (1999). The big-five trait taxonomy: History, measurement, and theoretical perspectives. In L. A. Pervin \& O. P. John (Eds.), Handbook of personality: Theory and research (Vol. 2, pp. 102-138). Guilford Press.

Karaman, N. G., Dogan, T., \& Coban, A. E. (2010). A study to adapt the big five inventory to Turkish. Procedia-Social and Behavioral Sciences, 2, 23572359. https://doi.org/10.1016/j.sbspro.2010.03.336

Lang, F. R., John, D., Lüdtke, O., Schupp, J., \& Wagner, G. G. (2011). Short assessment of the Big Five: Robust across survey methods except telephone interviewing. Behavior Research Methods, 43, 548-567. https://doi.org/10.3758/s13428-011-0066-Z

Laros, J. A., Peres, A. J. de S., Andrade, J. M. de, \& Passos, M. F. D. (2018). Validity evidence of two short scales measuring the Big Five personality factors. Psicologia: Reflexão e Crítica, 31(32). https://doi.org/10.1186/s41155-018-0111-2

Leung, Wong, Chan, \& Lam, 2013 - Leung, D. Y., Wong, E. M., Chan, S. S., \& Lam, T. H. (2013). Psychometric properties of the Big Five Inventory in a Chinese sample of smokers receiving cessation treatment: A validation study. Journal of Nursing Education and Practice, 3(6), 1-10. https://doi.org/10.5430/jnep.v3n6p1

Lorenzo-Seva. U., \& ten Berge, J. M. F. (2006). Tucker's congruence coefficient as a meaningful index of factor similarity. Methodology, 2(2), 57-64. https://doi.org/10.1027/1614-1881.2.2.57

Marsh, H. W., Lüdtke, O., Muthén, O., Asparouhov, T., Morin, A. J. S., Trautwein, U., \& Nagengast, B. (2010). A new look at the Big Five factor structure through exploratory structural equation modeling. Psychological Assessment, 22, 47-491. https://doi.org/10.1037/a0019227

McCabe, K. O., Van Yperen, N. W., Elliot, A. J., \& Verbraak, M. (2013). Big Five personality profiles of context-specific achievement goals. Journal of Research in Personality. 47 (6), 698-707. https://doi.org/10.1016/j.jrp.2013.06.003

McCrae, R.R. (1992). An introduction to the five-factor model and its applications. Journal of Personality, 60, 175-215. https://doi.org/10.1111/j.1467-6494.1992.tb00970.x

McCrae, R. R. (2011). Personality theories for the 21st century. Teaching of Psychology, 38, 209-214. https://doi.org/10.1177/0098628311411785

McCrae, R. R., Zonderman, A. B., Costa, P. T., Jr., Bond, M. H., \& Paunonen, S. V. (1996). Evaluating replicability of factors in the Revised NEO Personality Inventory: Confirmatory factor analysis versus Procrustes rotation. Journal of Personality and Social Psychology, 70, 552-566. http://dx.doi.org/10.1037/0022-3514.70.3.552

O'Keefe, D. F., Kelloway, E. K., \& Francis, R. (2012). Introducing the OCEAN.20: A 20-Item five-factor personality measure based on the trait self-descriptive inventory. Military Psychology, 24, 433-460. https://doi.org/10.1080/08995605.2012.716265

Ostendorf, F., \& Angleitner, A. (1994). A comparison of different instruments proposed to measure the Big Five. European Review of Applied Psychology, 44, 45-53. 
Plaisant, O., Courtois, R., Réveillère, C., Mendelsohn, G. A., \& John, O. P. (2010). Validation par analyse factorielle du Big Five Inventory Français (BFI-Fr). Analyse convergente avec le NEO-PI-R. Annales Médico-Psychologiques, Revue Psychiatrique, 168, 97-106. https://doi.org/10.1016/j.amp.2009.09.003

Parks, L., \& Guay, R. P. (2009). Personality, values, and motivation. Personality and Individual Differences, 47, 675-684. https://doi.org/10.1016/j.paid.2009.06.002

Paunonen, S. V., \& Jackson, D. N. (2000). What is beyond the Big Five? Plenty! Journal of Personality, 68, 821-835. https://doi.org/10.1111/14676494.00117

Rammstedt, B., \& John, O. P. (2007). Measuring personality in one minute or less: A 10-item short version of the Big Five Inventory in English and German. Journal of Research in Personality, 41, 203-212. https://doi.org/10.1016/j.jrp.2006.02.001

Roccas, S., Sagiv, L., Schwartz, S. H., \& Knafo, A. (2002). The big five personality factors and personal values. Personality and social psychology bulletin, 28(6), 789-801. https://doi.org/10.1177/0146167202289008

Saucier, G. (1994). Mini-markers: A brief version of Goldberg's unipolar Big-Five markers. Journal of Personality Assessment, 63, 506-516. https://doi.org/10.1207/s15327752jpa6303_8

Schmitt, D. P., Allik, J., McCrae, R. R., \& Benet-Martínez, V. (2007). The geographic distribution of Big Five personality traits patterns and profiles of human self-description across 56 nations. Journal of Cross-Cultural Psychology, 38, 173-212. https://doi.org/10.1177/0022022106297299

Silva, I. B., \& Nakano, T. D. C. (2011). Modelo dos Cinco Grandes Fatores da personalidade: Análise de pesquisas [Big Five factor model: Research analysis]. Avaliação Psicológica, 10, 51-62.

Spörrle, M., \& Bekk, M. (2014). Meta-analytic guidelines for evaluating single-item reliabilities of personality instruments. Assessment, 21(3), 272-285. https://doi.org/10.1177/1073191113498267

Soto, C. J., \& John, O. P. (2009). Ten facet scales for the Big Five Inventory: Convergence with NEO PI-R facets, self-peer agreement, and discriminant validity. Journal of Research in Personality, 43, 84-90. https://doi.org/10.1016/j.jrp.2008.10.002

Soto, C. J., \& John, O. P. (2012). Development of Big Five domains and facets in adulthood: Mean- level age trends and broadly versus narrowly acting mechanisms. Journal of Personality, 80, 881-914. https://doi.org/10.1111/j.1467-6494.2011.00752.x

Soto, C. J., \& John, O. P. (2017). Short and extra-short forms of the Big Five Inventory-2: The BFI-2-S and BFI-2-XS. Journal of Research in Personality, 68, 69-81. http://dx.doi.org/10.1016/j.jrp.2017.02.004

Srivastava, S., John, O. P., Gosling, S. D., \& Potter, J. (2003). Development of personality in early and middle adulthood: Set like plaster or persistent change?. Journal of personality and social psychology, 84(5), 1041-1053. https://doi.org/10.1037/0022-3514.84.5.1041

van der Linden, D., te Nijenhuis, J., \& Bakker, A. B. (2010). The General Factor of Personality: A meta-analysis of Big Five intercorrelations and a criterionrelated validity study. Journal of Research in Personality, 44, 315-327. https://doi.org/10.1016/j.jrp.2010.03.003 
Veloso gouveia, Rodrigues AraúJo, Vasconcelos de Oliveira, Pereira GonÇalves, Milfont, Lins de Holanda Coelho, SAntos, de Medeiros, Silva SoAres, Pereira Monteiro, Moura de Andrade, Medeiros Cavalcanti, da Silva Nascimento, \& Gouveia

van Sonderen, E., Sanderman, R., \& Coyne, J. C. (2013). Ineffectiveness of reverse wording of questionnaire ítems: Let's learn from cows in the rain. PLOS ONE 8(9). https://doi.org/10.1371/journal.pone.0068967

Woods, S. A., \& Hampson, S. E. (2005). Measuring the Big Five with single items using a bipolar response scale. European Journal of Personality, 19, 373-390. https://doi.org/10.1002/per.542

Worrell, F. C., \& Cross Jr., W. E. (2004). The reliability and validity of Big Five Inventory scores with African American college students. Journal of Multicultural Counseling and Development, 32, 18-32. https://doi.org/10.1002/j.2161-1912.2004.tb00358.x

Wright, A. G. C. (2017). Factor analytic support for the Five Factor Model. In T. A. Widiger (Ed.), The Oxford handbook of the Five Factor Model (pp. 217-242). Oxford University Press.

Yarkoni, T. (2010). The abbreviation of personality, or how to measure 200 personality scales with 200 items. Journal of Research in Personality, 44, 180-198. https://doi.org/10.1016/j.jrp.2010.01.002

Yuan, K., \& Bentler, P. M. (2002). On robustness of the normal-theory based asymptotic distributions of three reliability coeficiente estimates. Psychometrika, 67, 251-259.

https://doi.org/10.1016/j.jrp.2010.01.002 